Article

\title{
Resistance Evolution to EPSPS Inhibiting Herbicides in False Barley (Hordeum murinum) Harvested in Southern Spain
}

\author{
José G. Vázquez-García ${ }^{1}\left(\mathbb{D}\right.$, Patricia Castro ${ }^{2}$, Joel Torra ${ }^{3, *}{ }^{\circledR}$, Ricardo Alcántara-de la Cruz ${ }^{4}(\mathbb{D}$ \\ and Rafael De Prado ${ }^{1}$ D \\ 1 Department of Agricultural Chemistry and Edaphology, University of Cordoba, 14071 Cordoba, Spain; \\ z82vagaj@uco.es (J.G.V.-G.); qe1pramr@uco.es (R.D.P.) \\ 2 Departament of Genetics, University of Córdoba, 14071 Córdoba, Spain; patricia.castro@uco.es \\ 3 Department d'Hortofruticultura, Botànica i Jardineria, Agrotecnio, Universitat de Lleida, 25198 Lleida, Spain \\ 4 Departamento de Química, Universidade Federal de São Carlos, São Carlos 13565-905, Brazil; \\ ricardo.cruz@ufscar.br \\ * Correspondence: joel.torra@udl.cat; Tel.: +34-973702318
}

Received: 10 June 2020; Accepted: 8 July 2020; Published: 10 July 2020

check for updates

\begin{abstract}
A failure of the EPSPS-inhibiting herbicide glyphosate to control several populations of Hordeum murinum subsp. leporinum (or H. murinum) occurred in southern Spain after more than fifteen applications in both crop (olive, orchards, and citrus) and non-crop (dry areas, roadsides and ditches) areas. Eight out of 18 populations studied were resistant $(R)$ to glyphosate with $R$ factors higher than four based on $\mathrm{GR}_{50}$. These populations also had the highest values of $\mathrm{LD}_{50}$ and the lowest levels of shikimic acid accumulation. Two adjuvants tested increased glyphosate efficacy in both susceptible (S) and R populations thanks to better spray foliar retention. Moreover, PS I-, PS II-, and ACCase-inhibiting herbicides, in pre- or post-emergence, proved to be the best chemical alternatives with different sites of action (SoA) to control both $\mathrm{S}$ and glyphosate-R populations. This study represents the first report worldwide of glyphosate resistance in H. murinum found in very different crop and non-crop areas from southern Spain. To design chemical strategies to implement integrated weed management programs for glyphosate-R H. murinum, both adjuvants and herbicides with alternative SoA as well as application timings should be considered.
\end{abstract}

Keywords: adjuvant; alternative chemical control; foliar retention; fruit trees; glyphosate resistance; herbicide resistance; non-crop land; olive orchards; shikimik acid; wall barley

\section{Introduction}

Hordeum spp. is a genus of the Poaceae family widely distributed in the world, from Africa, Europe, and Asia to Central and North America [1,2]. In this genus, there are species with different reproduction systems ranging from highly autogamous to allogamous with genetic self-incompatibility [3], and also including both annual and perennial species [1]. Hordeum murinum subsp. leporinum (Link) Arcang (Syn. Hordeum murinum), also known as false barley or wall barley, is one of the most important species in the south of Spain in perennial and other crops under no-till. It is a winter annual weed and has become a serious threat to agricultural productivity in Spain in recent years. Moreover, this species has evolved resistance to herbicides due to its genetic diversity and biological, physiological, and ecological adaptations [4]. The evolution of herbicide resistance in $H$. murinum to several sites of action (SoA) has been confirmed mainly in Australia and has made these weed species more problematic for the agricultural community [5-14]. 
Historically, glyphosate has been the most used herbicide worldwide in annual and perennial crops $[15,16]$. The SoA of glyphosate (G for WSSA or 9 for HRAC) is the inhibition of the synthesis of essential amino acids for the plant by acting on the shikimic acid pathway [17]. The target protein of this herbicide is the chloroplast enzyme 5-enolpyruvylshikimate-3-phosphate synthase (EPSPS) that catalyzes the binding of shikimate-3-phosphate and phosphoenolpyruvate, ending with the production of chorismate, which is the precursor of the amino acids tyrosine, phenylalanine, and tryptophan, necessary for protein, cell wall, and secondary plant product synthesis [18].

This herbicide has become a popular weed control tool in agricultural systems owing to its broad spectrum weed control, high efficacy, and low cost compared with other herbicides [13], which resulted in the evolution of resistant (R) weeds around the world [19]. From an agronomic perspective, evolved herbicide resistance becomes a problem when weed control becomes "unacceptable" to a grower. This will typically happen when about 10 to $15 \%$ of weeds (normally considered susceptible, S) survive the herbicide application [20]. Therefore, an early detection of $\mathrm{R}$ weeds can contribute to improve integrated weed management (IWM) and thus to crop protection in agriculture. Herbicide resistance is the ability of a weed biotype to survive an herbicide application, where under normal circumstances that herbicide applied at the recommended rate should kill the weed [21]. This is an evolutionary process, and its impact generally depends on the genetics and biology of weed species and selection pressure with the same SoA, among other factors [22].

Up-to-date, 48 cases of glyphosate resistance have been confirmed in the world, of which 24 species belong to the poaceae family [14]. The resistance levels and resistance mechanisms of grass weeds are very variable, being the best studied genus: Lolium spp. [23,24], Chloris spp. [25-28], Echinochloa colona [29-31], Digitaria insularis [32], and Sorghum halepense [33-35]. The only case of glyphosate resistance in the genus Hordeum was detected in Australia in 2016 in the subspecies H. murinum subsp. glaucum (Steud.) Tzvelev. (Syn. Hordeum glaucum) [13]. Although gene amplification was deciphered as the resistance mechanism in H. murinum subsp. glaucum [13], in other grass weed species, both target-site and non-target-site resistance mechanisms can evolve. Reduced absorption, retention, impaired transport, metabolism, point mutations, and amplification of the EPSPS gene have been cited [23-35].

Andalusia currently has the highest concentration of cultivated trees in Europe, with a continuous woodland of more than 200 million trees [36]. Different types of fruit orchards are abundant, such as almond or citrus, among others, but olive orchards are, by far, the most prominent, covering a surface area that exceeds 1.5 million hectares [37]. Andalusia is the world's leading olive oil-producing region: Spain produces $33 \%$ of the world's olive oil, and the Andalusia region accounts for $80 \%$ of total Spanish output [38]. Most tree orchards are rain-fed, with high slopes where conventional tillage is the traditional soil management system used, leading to high erosion and a significant transport of organic carbon [37]. In the last decades, growers are increasingly implementing conservation agriculture techniques, such as no tillage, to avoid these problems. Under no-till weeds are usually managed with chemical tools, and glyphosate, the unique remaining non-selective herbicide registered in Europe, is the most applied. However, the overreliance on herbicides for weed control, particularly glyphosate, is boosting the evolution of several herbicide $\mathrm{R}$ weeds. Given the importance of tree orchards in the country, especially olives, and the need to optimize the resources invested, monitoring glyphosate resistance is crucial to design better IWM strategies.

Recently, control failures with glyphosate on H. murinum subsp. leporinum, H. murinum as from now, were reported in different locations in southern Spain (Andalusia). Usually, in those locations glyphosate was the only herbicide treatment for at least the last five years. The aim of this study was to investigate the glyphosate resistance in several putative $\mathrm{R}$ populations from this region and propose alternative chemical options for this weed species, which is essential to promote the development of integrated and multi-tactical strategies to prevent further development and propagation of resistance. Specifically, eighteen H. murinum populations were characterized by dose-response assays, accumulation of shikimic 
acid, foliar retention assays, and effects of adjuvants on glyphosate efficacy. In addition, herbicides with different SoA were studied as possible chemical alternatives to glyphosate in H. murinum.

\section{Materials and Methods}

\subsection{Plant Material and Growing Conditions}

Eighteen Spanish populations of H. murinum were studied in this work. Most of these populations were collected in Andalusia (located in the south of Spain) in spring-summer (2018) (Table 1). Three populations were collected from sites where glyphosate has never been applied and, hence, were considered as potentially $\mathrm{S}$ standards (populations $\mathrm{Hm} 7, \mathrm{Hm} 9$, and $\mathrm{Hm} 17$ in Table 1). The remaining 15 populations were collected at sites where glyphosate was applied for at least five years. The harvested populations were collected from 25 plants that survived the glyphosate field-dose $\left(1080 \mathrm{~g}\right.$ ae ha $\left.{ }^{-1}\right)$. The seeds were arranged in paper envelopes and stored in a cold chamber at $4{ }^{\circ} \mathrm{C}$ until the assays were performed. Then, the seeds of each population were mechanically scarified to remove traces of dry matter. Germination tests in Petri dishes $(60 \times 15 \mathrm{~mm})$ were performed (four Petri dishes per population with 25 seeds each one). The dishes were placed in a cold chamber at $4{ }^{\circ} \mathrm{C}$ for $48 \mathrm{~h}$ and then taken to a growth chamber $\left(26^{\circ} \mathrm{C}\right.$ day $/ 18^{\circ} \mathrm{C}$ night), with $60 \%$ relative humidity and a photoperiod of $16 \mathrm{~h}$ at a light density of $850 \mathrm{mmol} \mathrm{m}^{-2} \mathrm{~s}^{-1}$, obtaining germination rates between 80 and $85 \%$ for each population. The germinated seeds were grown to produce seedlings as necessary for the assays described below.

Table 1. Populations of H. murinum employed in this study, code assigned to each population, location, crops, historical herbicide application, and coordinates of their locations.

\begin{tabular}{lllcc}
\hline Code & Location & Crops & H. Application & Coordinates \\
\hline Hm1 & Cordoba & Orchard & Many years using glyphosate & $37.708194,-4.789167$ \\
Hm2 & Cordoba & Orchard & Many years using glyphosate & $37.709861,-4.788778$ \\
Hm3 & Cordoba & No crop & Tank mix a & $37.695903,-4.504091$ \\
Hm4 & Cordoba & Orchard & Many years using glyphosate & $37.548358,-4.275374$ \\
Hm5 & Cordoba & Orchard & Many years using glyphosate & $37.709694,-4.806389$ \\
Hm6 & Cordoba & Orchard & Many years using glyphosate & $37.696306,-4.816556$ \\
Hm7 & Cordoba & No crop & Mechanical control & $37.914798,-4.714411$ \\
Hm8 & Cordoba & No crop & Tank mix a & $37.646018,-4.3771$ \\
Hm9 & Lleida & Vineyard & Mechanical control & $41.679000,0.474111$ \\
Hm10 & Cordoba & No crop & Tank mix a & $37.506787,-4.847001$ \\
Hm11 & Sevilla & Olive & Many years using glyphosate & $37.511594,-4.842501$ \\
Hm12 & Sevilla & Olive & Many years using glyphosate & $37.513054,-4.841346$ \\
Hm13 & Sevilla & Olive & Many years using glyphosate & $37.509776,-4.838388$ \\
Hm14 & Sevilla & Olive & Many years using glyphosate & $37.575327,-4.985865$ \\
Hm15 & Sevilla & Olive & Many years using glyphosate & $37.536481,-4.959472$ \\
Hm16 & Malaga & Olive & Many years using glyphosate & $36.974889,-4.918069$ \\
Hm17 & Sevilla & Cereal & ACCase inhibitors & $37.511594,-4.842501$ \\
Hm18 & Malaga & Olive & Many years using glyphosate & $37.039433,-4.553680$ \\
\hline
\end{tabular}

a Mix of herbicides used to control grass and broadleaf weeds in roads. No more information available. Populations $\mathrm{Hm} 7, \mathrm{Hm} 9$, and $\mathrm{Hm} 17$ are putative susceptible standard populations.

Seedlings of the eighteen populations were transplanted into $250 \mathrm{~mL}(7 \times 7 \times 5 \mathrm{~cm})$ pots (one plant per plot) with $230 \mathrm{~g}$ of substrate (soil:peat moss (1:1)). The plants were taken to the greenhouse and irrigated daily as necessary close to field capacity until the pertinent assays, undertaken in January 2019, at the University of Cordoba.

\subsection{Dose-Response Curves}

This test was performed on ten whole plants with three to four true leaves from each population. Glyphosate doses of 0, 31.25, 62.5, 125, 250, 500, 1000, 1500, and $2000 \mathrm{~g}$ ae ha ${ }^{-1}$ were applied with a treatment chamber (SBS-060 De Vries Manufacturing, Hollandale, MN, USA) equipped with 8002 flat fan nozzles and delivering $200 \mathrm{~L} \mathrm{ha}^{-1}$ at $250 \mathrm{KPa}$. The experiments were conducted using a completely randomized design with 10 repetitions per dose of glyphosate. Twenty-one days after 
application (DAA), plants were cut at the ground level and oven-dried at $60^{\circ} \mathrm{C}$ for $48 \mathrm{~h}$. Then, the plants were weighed, and values transformed to the percentage of dry weight reduction with respect to the untreated control to determine the herbicide rate inhibiting plant growth to $50 \%\left(\mathrm{GR}_{50}\right)$. In addition, plant mortality per dose was evaluated to determine the lethal dose that kills $50 \%$ of a population $\left(\mathrm{LD}_{50}\right)$. The experiments were repeated twice.

\subsection{Shikimic Acid Accumulation}

Disks of fresh leaf tissue ( $50 \mathrm{mg}$ ) were taken from individual plants (10 plants per population; three replications per population) and transferred to $2 \mathrm{~mL}$ Eppendorf tubes. Following the methodology described by Shaner et al. [39] with some modifications, $1 \mathrm{~mL}$ of monoammonium phosphate $\left(\mathrm{NH}_{4} \mathrm{H}_{2} \mathrm{PO}_{4} 10 \mathrm{mM}, \mathrm{pH} 4.4\right)$ plus glyphosate at $1000 \mu \mathrm{M}$ were added. The samples were incubated for $24 \mathrm{~h}$ under fluorescent light $\left(150 \mu \mathrm{M} \mathrm{m}^{-2} \mathrm{~s}^{-1}\right)$. Then, the samples were frozen and stored at $-20^{\circ} \mathrm{C}$ until used. The frozen samples were incubated at $60^{\circ} \mathrm{C}$ for $30 \mathrm{~min}$. Next, $250 \mu \mathrm{L}$ of hydrochloric acid ( $\mathrm{HCl}$ $1.25 \mathrm{~N}$ ) was added followed by incubation at $60^{\circ} \mathrm{C}$ for $15 \mathrm{~min}$. Aliquots of $250 \mu \mathrm{L}$ were transferred to $1.5 \mathrm{~mL}$ Eppendorf tubes containing $500 \mu \mathrm{L}$ of periodic acid $(0.25 \% \mathrm{w} / \mathrm{v})$ and sodium metaperiodate $(0.25 \% \mathrm{w} / \mathrm{v})$ solution in proportion $(1: 1(\mathrm{v} / \mathrm{v}))$. The tubes were incubated at room temperature $\left(25^{\circ} \mathrm{C}\right)$ for $90 \mathrm{~min}$. Then, $500 \mu \mathrm{L}$ of a mix containing sodium hydroxide $(\mathrm{NaOH} 0.6 \mathrm{~N})$ and sodium sulfite $\left(\mathrm{Na}_{2} \mathrm{SO}_{3}, 0.22 \mathrm{~N}\right)$ in a 1:1 ratio was added. Absorbance at $380 \mathrm{~nm}$ was measured in all samples using a spectrophotometer mod. DU-640 (Beckman Instruments Inc., Fullerton, CA, USA). The absorbance results were expressed as micrograms of shikimate per $\mathrm{g}^{-1}$ fresh weight $(\mathrm{mg} / \mathrm{g})$ using a calibration curve with known concentrations of shikimate. The experiment had a completely randomized design and was repeated twice.

\subsection{Adjuvant Effectiveness Assays}

For this assay, the most $\mathrm{S}$ and $\mathrm{R}$ populations were selected based on the data obtained in the dose-response experiments. Plants at three- to four-leaf stage were sprayed with glyphosate at a dose of $100 \mathrm{~g}_{\text {ae ha }}{ }^{-1}$ for the $\mathrm{Hm} 10$ population (lowest dose of $\mathrm{GR}_{50}$ ), the $\mathrm{S}$ population, and $750 \mathrm{~g}$ ae ha ${ }^{-1}$ for $\mathrm{Hm} 2$ population (highest dose of $\mathrm{GR}_{50}$ value), the $\mathrm{R}$ one. Two adjuvants were added to each dose of glyphosate at the recommended doses $\left(1 \mathrm{~mL} \mathrm{~L}^{-1}\right.$ Trend 90; $2 \mathrm{~mL} \mathrm{~L}^{-1}$ Retenol). The applications were performed with the same calibration and chamber sprayer described above. After spraying, the plants were maintained for 21 DAA in the greenhouse. Then, the plants were cut at ground level and shoots were dried at $60^{\circ} \mathrm{C}$ for two days. The experimental design was completely randomized with four replications, and each replicate included three plants from each population. Next, the plants were evaluated by determining the reduction of dry weight. Furthermore, the increase of effectiveness (IE) of the glyphosate was determined with each adjuvant $\{\mathrm{IE}=[(\mathrm{dwGA}-\mathrm{dwG}) / \mathrm{dwG}] \times 100\}$ where $\mathrm{dwGA}$ is the dry weight reduction with glyphosate plus adjuvant and $\mathrm{dwG}$ is the dry weight reduction with glyphosate only [40]. This represents the increase in the activity of the glyphosate with adjuvants. Assays were conducted twice.

\subsection{Foliar Retention Assay}

The methodology used for the foliar retention was described by Gauvrit [41]. Six plants of Hm10 (putative S) and $\mathrm{Hm} 2$ (putative R) populations were sprayed with $360 \mathrm{~g}$ ae ha ${ }^{-1}$ of glyphosate plus adjuvants (at the doses mentioned in adjuvant effectiveness) and $100 \mathrm{mg} \mathrm{L}^{-1} \mathrm{Na}$-fluorescein using the same calibration and conditions described above. Plants were cut at ground level when they dried (40 to $60 \mathrm{~min}$ ). Shoot tissue was submerged in test tubes containing $50 \mathrm{~mL}$ of $5 \mathrm{mM} \mathrm{NaOH}$ for $30 \mathrm{~s}$ to remove spray solution. The washing solution was recovered in glass flasks. Fluorescein absorbance was determined using a spectrofluorometer (Hitachi F-2500, Tokyo, Japan) with excitation wavelength of $490 \mathrm{~nm}$ and absorbance at $510 \mathrm{~nm}$. Then, the plants were wrapped in filter paper and oven-dried at $60{ }^{\circ} \mathrm{C}$ for $48 \mathrm{~h}$ and weighed. The experimental design was the same as that of the previous section. 
Foliar retention was expressed as $\mu \mathrm{L} \mathrm{g}^{-1}$ of spraying solution per gram of dry weight. Afterwards, the increase of effectiveness (IE) of glyphosate retention was determined as above.

\subsection{Alternative Chemical Control}

The putative S (Hm10) and a putative $\mathrm{R}(\mathrm{Hm} 2)$ population of H. murinum were sprayed with 10 different herbicides (at field and half field doses) which belonged to seven different SoA (WSSA; HRAC) (Table 2). The application of the herbicides was done on 10 plants with 3-4 true leaves from each population. The applications were made with the application chamber previously described in the dose-response section. Visual assessments were made at 7, 14, 21 (data not shown), and 28 DAA, to determine the percentage of injury in each population. The injury was evaluated considering the presence of chlorosis or reduced growth with respect to an untreated plant, $0 \%$ attributed when there was no injury, and 100\% when there was total control of the plants by herbicides. H. murinum control was considered unsatisfactory when plant survival was greater than or equal to $15 \%$. Surviving plants at 28 DAA were also evaluated. In this step, the plants were cut at ground level and weighed. Fresh weight data were transformed into percentage of fresh weight reduction with respect to the untreated control for each herbicide. The experiment was repeated twice in a completely randomized design using ten plants per dose and population.

Table 2. Chemical treatments applied to two populations of H. murinum (Hm2 and Hm10) in pre- or post-emergence under greenhouse conditions.

\begin{tabular}{ccccc}
\hline Active Ingredient & SoA $^{\mathbf{a}}$ & HRAC $($ WSSA Group) & Doses (g ai ha $^{\mathbf{- 1}}$ ) & Timing $^{\text {Him }}$ \\
\hline Propaquizafop & ACCase & A (1) & 62.5 and 125 & Post \\
Quizalofop & ACCase & A (1) & 50 and 100 & Post \\
Iodosulfuron & ALS & B (2) & 2.5 and 5 & Post \\
Flazasulfuron & ALS & B (2) & 25 and 50 & Pre \\
Paraquat & PS I & D (22) & 200 and 400 & Post \\
Oxyfluorfen & PPO & E (14) & 250 and 500 & Pre \\
Glufosinate & GS & H (10) & 250 and 500 & Post \\
Tembotrione & HPPD & $\mathrm{F}_{2}(27)$ & 60 and 120 & Post \\
Diuron & PS II & $\mathrm{C}_{2}(7)$ & 900 and 1800 & Pre \\
Atrazine & PS II & $\mathrm{C}_{1}(5)$ & 1000 and 2000 & Pre \\
\hline
\end{tabular}

${ }^{a}$ Site of Action, abbreviations: Acetyl CoA carboxylase (ACCase); Acetolactate synthase (ALS); Photosystem I-electron diversion (PS I); Protoporphyrinogen oxidase (PPO); Glutamine synthetase (GS); 4-hydroxyphenylpyruvate dioxygenase (HPPD) and Photosystem II (PSII).

\subsection{Data Analysis}

The results of the dose-response trials were subjected to nonlinear regression using Formula (1), with which the herbicide dose required to reduce growth by $50 \%\left(\mathrm{GR}_{50}\right)$ and to kill $50 \%$ of a population $\left(\mathrm{LD}_{50}\right)$ was estimated,

$$
y=d /\{1+\exp [b(\log x-\log e)]\}
$$

where $y$ represents shoot dry weight and survival as a percentage of non-treated control at herbicide rate of $x, d$ is the upper limit, $e$ represents $\mathrm{GR}_{50}$ and $\mathrm{LD}_{50}$, and $b$ is curve slope in $e$. Resistance factor (RF) was calculated with Formula (2),

$$
\mathrm{RF}=\left(\mathrm{GR}_{50} \text { or } \mathrm{LD}_{50} \mathrm{R} / \mathrm{GR}_{50} \text { or } \mathrm{LD}_{50} \mathrm{~S}\right)
$$

where " $R$ " refers to a $R$ population and " $S$ " to a $S$ population.

Regression analyses were conducted using the drc package [42] with the program $\mathrm{R}$ version 3.6.1 (R Core Team, 2020) and the data were plotted using SigmaPlot 12.0 (Systat Software, Inc., San Jose, CA, USA). 
Data of shikimic acid accumulation, adjuvant effectiveness, foliar retention, and alternative chemical controls were subjected to Analysis of Variance (ANOVA) using the Statistix software v10.0 (Analytical software, Tallahassee, FL, USA). The model assumptions of a normal error distribution and homogeneous variance were graphically inspected. When differences were considered significant, a Tukey's test $(p<0.05)$ was conducted to compare the means.

\section{Results}

\subsection{Dose-Response Assays}

The estimated parameters of each population are shown in Table 3. Eighteen populations of H. murinum showed different levels of susceptibility to glyphosate, with $\mathrm{GR}_{50}$ values ranging from 122.8 to $172.6 \mathrm{~g}$ ae $\mathrm{ha}^{-1}$ in very S populations ( $\mathrm{Hm} 7, \mathrm{Hm} 9, \mathrm{Hm} 10$, and $\left.\mathrm{Hm} 17\right)$, to 665.7 to $1081.6 \mathrm{~g}$ ae ha ${ }^{-1}$ in highly R populations ( $\mathrm{Hm} 1, \mathrm{Hm} 2, \mathrm{Hm} 6$, and $\mathrm{Hm} 14$ ). The remainder of the populations had intermediate $\mathrm{GR}_{50}$ values. Based on these values, RF varied among populations (Figure 1), Hm2 population was 8.8 times more $R$ than $H m 10$, which was the most $S$ population. The $\mathrm{LD}_{50}$ of $\mathrm{Hm} 10$ was $318.6 \mathrm{~g}_{\text {ae ha }}{ }^{-1}$, while the $\mathrm{LD}_{50}$ of five populations exceeded the field dose established in Spain (1080 $\mathrm{g}$ ae $\mathrm{ha}^{-1}$ ) (Table 3 ), which killed all S populations. Based on $\mathrm{LD}_{50}$, again the $\mathrm{Hm} 2$ population was the most $\mathrm{R}$ (6.2) compared to the most $\mathrm{S}$ one (Hm10).

Table 3. $\mathrm{GR}_{50}$ and $\mathrm{LD}_{50}$ values ( $\mathrm{g}$ ae ha ${ }^{-1}$ ) of glyphosate-resistant and -susceptible H. murinum populations.

\begin{tabular}{|c|c|c|c|c|c|c|c|c|}
\hline \multicolumn{9}{|c|}{ Parameters ${ }^{a}$ Calculated Using Non-Linear Regression ${ }^{b}$} \\
\hline Population & $b$ & $d$ & $\mathbf{G R}_{50}$ & $\mathbf{R F}^{\mathrm{c}}$ & $b$ & $d$ & $\mathrm{LD}_{50}$ & $\mathbf{R F}^{\mathrm{c}}$ \\
\hline Hm1 & 1.5 & 98.1 & $794.1 \pm 62.9$ & 6.5 & 5.3 & 98.8 & $1427.8 \pm 61.7$ & 4.5 \\
\hline $\mathrm{Hm} 2$ & 2.4 & 93.4 & $1081.6 \pm 56.5$ & 8.8 & 7.2 & 100.1 & $1977.9 \pm 21.8$ & 6.2 \\
\hline $\mathrm{Hm} 3$ & 1.4 & 97.2 & $277.0 \pm 26.4$ & 2.3 & 2.8 & 99.5 & $447.7 \pm 22.3$ & 1.4 \\
\hline $\mathrm{Hm} 4$ & 3.2 & 97.2 & $225.1 \pm 12.1$ & 1.8 & 2.0 & 97.9 & $373.0 \pm 44.2$ & 1.2 \\
\hline $\mathrm{Hm} 5$ & 1.8 & 93.2 & $504.8 \pm 49.9$ & 4.1 & 3.3 & 100.2 & $1024.7 \pm 61.6$ & 3.2 \\
\hline Hm6 & 1.5 & 96.7 & $665.7 \pm 65.7$ & 5.4 & 4.9 & 98.8 & $1165.1 \pm 50.0$ & 3.7 \\
\hline $\mathrm{Hm} 7$ & 2.5 & 99.4 & $150.0 \pm 9.0$ & 1.2 & 1.9 & 101.3 & $343.4 \pm 30.7$ & 1.1 \\
\hline $\mathrm{Hm} 8$ & 1.6 & 98.5 & $549.4 \pm 42.9$ & 4.5 & 4.5 & 97.0 & $1111.3 \pm 59.3$ & 3.5 \\
\hline $\mathrm{Hm} 9$ & 2.5 & 99.7 & $170.0 \pm 10.1$ & 1.4 & 3.3 & 100.5 & $388.0 \pm 21.1$ & 1.2 \\
\hline $\mathrm{Hm} 10$ & 1.5 & 99.1 & $122.8 \pm 10.7$ & - & 1.9 & 100.0 & $318.6 \pm 14.1$ & - \\
\hline $\mathrm{Hm} 11$ & 1.7 & 97.6 & $269.5 \pm 19.4$ & 2.2 & 2.1 & 99.9 & $659.2 \pm 9.9$ & 2.1 \\
\hline $\mathrm{Hm} 12$ & 3.3 & 95.0 & $515.3 \pm 20.8$ & 4.2 & 2.7 & 100.0 & $802.0 \pm 21.8$ & 2.5 \\
\hline Hm13 & 3.1 & 91.7 & $494.0 \pm 24.3$ & 4.0 & 2.6 & 100.0 & $775.5 \pm 15.0$ & 2.4 \\
\hline Hm14 & 3.4 & 95.8 & $940.9 \pm 30.7$ & 7.7 & 3.8 & 100.4 & $1644.7 \pm 55.8$ & 5.2 \\
\hline Hm15 & 7.7 & 95.9 & $280.1 \pm 12.1$ & 2.3 & 4.6 & 99.6 & $413.8 \pm 13.2$ & 1.3 \\
\hline Hm16 & 6.4 & 98.0 & $363.0 \pm 15.3$ & 3.0 & 6.4 & 97.6 & $639.7 \pm 13.1$ & 2.0 \\
\hline $\mathrm{Hm} 17$ & 2.5 & 99.9 & $172.6 \pm 5.8$ & 1.4 & 3.2 & 100.1 & $322.1 \pm 13.4$ & 1.01 \\
\hline $\mathrm{Hm} 18$ & 7.1 & 97.8 & $290.5 \pm 6.2$ & 2.4 & 9.8 & 99.2 & $471.8 \pm 28.2$ & 1.5 \\
\hline
\end{tabular}

${ }^{\mathrm{a}} y=d /\{1+\exp [b(\log x-\log e)]\}$, where $b$ is the relative slope around $e, d$ is the upper limit. GR ${ }_{50}$ in $\mathrm{g}$ ae ha ${ }^{-1}$ is the amount of glyphosate required to reduce dry weight by $50 \%, \mathrm{LD}_{50}$ is the glyphosate dose required for $50 \%$ mortality. ${ }^{b}$ Mean \pm standard error (SE). ${ }^{c} \mathrm{RF}=$ Resistance factor $(\mathrm{R} / \mathrm{S})$ calculated using the $\mathrm{GR}_{50}$ or $\mathrm{LD}_{50}$ values of the resistant populations respect to the most susceptible population. 


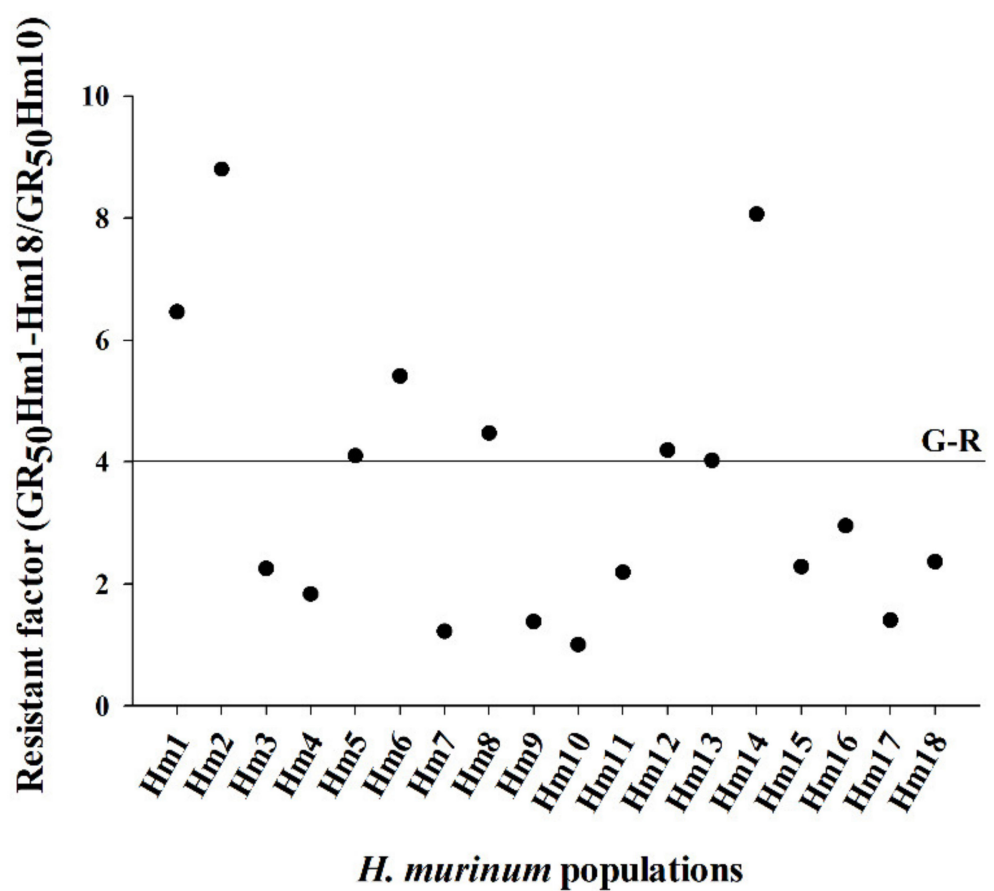

Figure 1. Resistant factor $(\mathrm{RF})$ of $18 \mathrm{H}$. murinum populations from Spain based on $\mathrm{GR}_{50}$. Population Hm10 was the reference population to estimate RF. The line represents the minimum $R F(\geq 4)$ accepted to consider a glyphosate-resistant (G-R) population [14].

\subsection{Shikimic Acid Accumulation}

The response of 18 populations was different at $1000 \mu \mathrm{M}$ of glyphosate. Hm10 population had the maximum level of shikimic acid accumulation $\left(0.16 \mathrm{mg} \mathrm{g}^{-1}\right.$ fresh weight), four times more than $\mathrm{Hm} 2$ (0.04 $\mathrm{mg} \mathrm{g}^{-1}$ fresh weight); the rest of the populations were around these values (Figure 2).

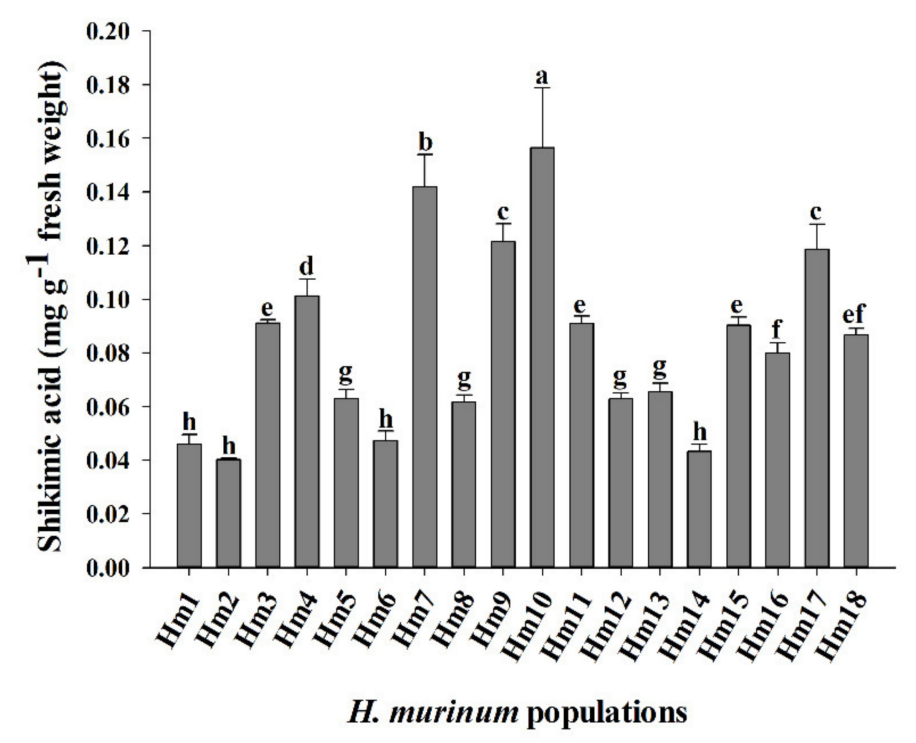

Figure 2. Shikimic acid accumulation in $18 \mathrm{H}$. murinum populations from Spain. Means with different letters are statistically different at $95 \%$ probability according to the Tukey's test. 


\subsection{Adjuvant Effectiveness Assays}

Although 7.5-fold more glyphosate was applied to the R population than to the $\mathrm{S}$ one, the \% of dry weight reduction was similar in both populations when adjuvants were not added to the glyphosate (Table 4). On the other hand, the increase of effectiveness (IE) of glyphosate augmented significantly with the addition of adjuvants in both $S$ and $R$ populations. The effects were stronger in the R population, with IE values of $92 \%$ and 105\% for Retenol and Trend 90 adjuvants, respectively, while in the S population values were $48 \%$ and $73 \%$ (Table 4 ). Trend 90 adjuvant was slightly better than Retenol in increasing glyphosate efficacy in both populations.

Table 4. Glyphosate (Gly) activity in dry weight (dw) reduction (\%) and increase of effectiveness (IE) with and without adjuvants in putative resistant (R) and susceptible (S) H. murinum populations.

\begin{tabular}{|c|c|c|c|c|}
\hline \multirow{2}{*}{ Treatment } & \multicolumn{4}{|c|}{ dw Reduction (\%) } \\
\hline & $R^{a}\left(750 g^{a e ~ h a} a^{-1}\right)^{a}$ & IE (\%) & $S^{a}\left(100 g_{\text {ae }} a^{-1}\right)$ & IE (\%) \\
\hline Gly & $36.6 \pm 4.5 b$ & - & $40.3 \pm 1.7 b$ & - \\
\hline Gly + Retenol & $70.3 \pm 3.3 \mathrm{a}$ & 91.9 & $59.7 \pm 4.1 \mathrm{a}$ & 48.3 \\
\hline Gly + Trend 90 & $75.0 \pm 5.4 \mathrm{a}$ & 104.9 & $69.5 \pm 3.3 a$ & 72.7 \\
\hline
\end{tabular}

a Means within a column followed by the same letter are not significantly different at the $5 \%$ level as determined by the Tukey test. Mean values \pm standard errors of the mean.

\subsection{Foliar Retention Assays}

At $360 \mathrm{~g}$ ae ha ${ }^{-1}$, foliar retentions of glyphosate were similar in the $\mathrm{R}$ and $\mathrm{S}$ populations for each of the treatments (Table 5). It should be highlighted that the herbicide foliar retention increased significantly in both populations when each one of the adjuvants were added. However, Trend 90 adjuvant was significantly better than Retenol in increasing the retention in both populations; the value in terms of $\mu \mathrm{L}$ of glyphosate $\mathrm{g}^{-1}$ dry weight was nearly two-fold higher, and the differences in IE values were higher than $100 \%$ (Table 5).

Table 5. Foliar retention of glyphosate (Gly) at $360 \mathrm{~g}$ ae ha ${ }^{-1}$ and increase of effectiveness (IE) with and without adjuvants in resistant (R) and susceptible (S) H. murinum populations.

\begin{tabular}{ccccc}
\hline \multirow{2}{*}{ Treatment } & \multicolumn{4}{c}{ Mean ${ }^{\mathbf{a}}\left(\mu \mathbf{L ~ g}^{-\mathbf{1}}\right.$ dry weight) } \\
\cline { 2 - 5 } & $\mathbf{R}$ & IE (\%) & $\mathbf{S}$ & IE (\%) \\
\hline Gly & $447.5 \pm 14.4 \mathrm{c}$ & - & $467.25 \pm 13.2 \mathrm{c}$ & - \\
\hline Gly + Retenol & $638.75 \pm 12.1 \mathrm{~b}$ & 42.7 & $631.75 \pm 7.8 \mathrm{~b}$ & 35.2 \\
\hline Gly + Trend 90 & $1133.75 \pm 12.5 \mathrm{a}$ & 153.4 & $1222.5 \pm 15.5 \mathrm{a}$ & 161.6 \\
\hline
\end{tabular}

a Means within a column followed by the same letter are not significantly different at the $5 \%$ level as determined by the Tukey test. Mean values \pm standard errors of the mean.

\subsection{Alternative Chemical Control}

In this research, H. murinum (e.g., Hm2) from southern Spain was R to glyphosate. Results showed that it is possible to control these $\mathrm{R}$ populations applying herbicides with different SoA. The PS II (atrazine), the PS I (paraquat), and ACCase (propaquizafop and quizalafop) inhibitors were the best alternative herbicides for controlling the $\mathrm{R}$ and S populations at field and half doses, with $100 \%$ of visual control, no survival, and $100 \%$ of fresh weight reduction (Table 6). Diuron (PS II inhibitor) and flazasulfuron (ALS inhibitor) had unequal effects on $S$ and R populations; although visual injury had always the maximum value, fresh reduction was $100 \%$ at both doses only in the $S$ population. None of the plants from the $S$ population survived at any of the doses, while $50-60 \%$ of the plants from the R population survived at the highest doses of these herbicides. Oxyfluorfen (PPO inhibitor) and glufosinate (glutamine synthetase inhibitor) showed excellent visual control (100\%) and good 
fresh weight reductions levels (66-99\%). However, plant survivals for these two herbicides were generally too high (60-100\%) and the only acceptable value (10\%) was obtained when the R population was treated with the highest doses of glufosinate. Finally, the worst options were the ALS inhibitor iodosulfuron and the HPPD inhibitor tembotrione, with 0-30\% of visual control, all plants surviving and very low levels of fresh weight reduction (Table 6).

Table 6. Effect of alternative herbicides to control putative resistant (R) and susceptible (S) H. murinum populations (Hm2 and $\mathrm{Hm} 10$, respectively) at 28 days after application, visual evaluation, survival plant, and fresh weight (fw) reduction.

\begin{tabular}{|c|c|c|c|c|c|c|c|c|c|c|c|c|c|}
\hline \multirow{3}{*}{$\begin{array}{c}\text { Herbicides } \\
\begin{array}{c}\text { Check } \\
\text { (untreated) }\end{array} \\
\end{array}$} & \multirow{3}{*}{ Doses (g ai ha-1) } & \multicolumn{4}{|c|}{ Visual Evaluation $^{a}$} & \multicolumn{4}{|c|}{$\%$ Survival Plant ${ }^{b}$} & \multicolumn{4}{|c|}{$\%$ fw Reduction ${ }^{c}$} \\
\hline & & \multicolumn{2}{|l|}{$S$} & \multicolumn{2}{|l|}{$\mathbf{R}$} & \multicolumn{2}{|l|}{$\mathrm{S}$} & \multicolumn{2}{|l|}{$\mathbf{R}$} & \multicolumn{2}{|l|}{$\mathrm{S}$} & \multicolumn{2}{|l|}{$\mathbf{R}$} \\
\hline & & 0 & $\mathrm{D}$ & 0 & $\mathrm{C}$ & 100 & A & 100 & A & 0 & $\mathrm{D}$ & 0 & I \\
\hline \multirow{2}{*}{ Propaquizafop } & 62.5 & 100 & A & 100 & A & 0 & $\mathrm{D}$ & 0 & $\mathrm{~F}$ & 100 & A & 100 & A \\
\hline & 125 & 100 & $\mathrm{~A}$ & 100 & A & 0 & $\mathrm{D}$ & 0 & $\mathrm{~F}$ & 100 & A & 100 & A \\
\hline \multirow{2}{*}{ Quizalofop } & 50 & 100 & A & 100 & A & 0 & D & 0 & F & 100 & A & 100 & A \\
\hline & 100 & 100 & $\mathrm{~A}$ & 100 & A & 0 & $\mathrm{D}$ & 0 & F & 100 & $\mathrm{~A}$ & 100 & A \\
\hline \multirow{2}{*}{ Iodosulfuron } & 2.5 & 0 & $\mathrm{D}$ & 0 & $\mathrm{C}$ & 100 & $\mathrm{~A}$ & 100 & A & 5.83 & $\mathrm{D}$ & 0 & I \\
\hline & 5 & 0 & $\mathrm{D}$ & 0 & $\mathrm{C}$ & 100 & $\mathrm{~A}$ & 100 & A & 5 & $\mathrm{D}$ & 10.36 & $\mathrm{H}$ \\
\hline \multirow{2}{*}{ Flazasulfuron } & 25 & 100 & $\mathrm{~A}$ & 100 & $\mathrm{~A}$ & 0 & $\mathrm{D}$ & 100 & A & 100 & A & 57.31 & E \\
\hline & 50 & 100 & $\mathrm{~A}$ & 100 & A & 0 & $\mathrm{D}$ & 50 & $\mathrm{D}$ & 100 & $\mathrm{~A}$ & 93.29 & B \\
\hline \multirow{2}{*}{ Paraquat } & 200 & 100 & A & 100 & A & 0 & D & 0 & F & 100 & A & 100 & A \\
\hline & 400 & 100 & A & 100 & A & 0 & $\mathrm{D}$ & 0 & F & 100 & A & 100 & A \\
\hline \multirow{2}{*}{ Oxyfluorfen } & 250 & 100 & $\mathrm{~A}$ & 100 & A & 100 & A & 100 & A & 78.5 & $\mathrm{~B}$ & 66.46 & D \\
\hline & 500 & 100 & A & 100 & A & 65 & $\mathrm{C}$ & 75 & B & 95.83 & A & 87.80 & C \\
\hline \multirow{2}{*}{ Glufosinate } & 250 & 100 & A & 100 & A & 85 & B & 60 & C & 80 & B & 83.53 & C \\
\hline & 500 & 100 & $\mathrm{~A}$ & 100 & A & 65 & $\mathrm{C}$ & 10 & E & 81.6 & B & 98.78 & A \\
\hline \multirow{2}{*}{ Tembotrione } & 60 & 0 & $\mathrm{D}$ & 0 & $\mathrm{C}$ & 100 & A & 100 & A & 28.33 & $\mathrm{C}$ & 18.29 & G \\
\hline & 120 & 30 & $\mathrm{C}$ & 25 & $\mathrm{~B}$ & 100 & A & 100 & A & 30.83 & $\mathrm{C}$ & 25.60 & F \\
\hline \multirow{2}{*}{ Diuron } & 900 & 85 & B & 100 & A & 0 & $\mathrm{D}$ & 75 & B & 100 & A & 68.29 & D \\
\hline & 1800 & 85 & B & 100 & A & 0 & $\mathrm{D}$ & 60 & $\mathrm{C}$ & 100 & A & 93.9 & B \\
\hline \multirow{2}{*}{ Atrazine } & 1000 & 100 & A & 100 & A & 0 & $\mathrm{D}$ & 0 & F & 100 & A & 100 & A \\
\hline & 2000 & 100 & $\mathrm{~A}$ & 100 & $\mathrm{~A}$ & 0 & $\mathrm{D}$ & 0 & F & 100 & $\mathrm{~A}$ & 100 & A \\
\hline
\end{tabular}

${ }^{a}$ The visual evaluation was based on the vigor and chlorosis of the plant, compared to the untreated check, with $0 \%$ attributed when there was no injury and $100 \%$ when there was total control of the plants by herbicides. ${ }^{b}$ H. murinum control was considered unsatisfactory when plant survival was greater than or equal to $15 \%$. ${ }^{\mathrm{c}}$ Means with different letter within a column are statistically different at $95 \%$ probability determined by the Tukey's test.

\section{Discussion}

Eighteen H. murinum populations were studied for resistance to glyphosate. Most of them were from Andalusia (southern Spain), mainly from olive orchards, but also from other types and non-crop land too. Eight populations had RF higher than four based on $\mathrm{GR}_{50}$, and three of them based on $\mathrm{LD}_{50}$ (Table 3 and Figures 1 and 3). According to the definition of herbicide resistance, RF must be higher than four [14]. Therefore, our study represents the first report worldwide of glyphosate resistance in H. murinum subsp. leporinum. It should be noted that, in this species, resistance to glyphosate has only been reported in an Australian H. murinum subsp. glaucum population [13]. Therefore, our study is the second global case for this species and the first one for Europe.

The levels of shikimic acid accumulation across populations confirmed the above-mentioned results. The three putative $S$ populations, or those with RF lower than two, showed two- to four-fold higher concentrations, while the ascribed R populations showed the lowest values (Figure 2). Significant lower levels of shikimic acid in $\mathrm{R}$ compared to $\mathrm{S}$ populations are accepted as quick and easy indicators for confirming glyphosate resistance [39]. Moreover, there was a clear relationship between the three resistance indicators evaluated to assess the levels of herbicide resistance. When a RF was also 
estimated for shikimic acid (ratio between $\mathrm{R}$ and $\mathrm{S}$ populations), the lowest values in $\mathrm{S}$ populations corresponded always to lowest $\mathrm{RF}$ for $\mathrm{GR}_{50}$ and $\mathrm{LD}_{50}$ too (Figure 3). In $\mathrm{R}$ populations, the highest $\mathrm{RF}$ for shikimic acid accumulation corresponded to $\mathrm{RF}\left(\mathrm{GR}_{50}\right)$ higher than four and usually higher than three based on $\mathrm{LD}_{50}$.

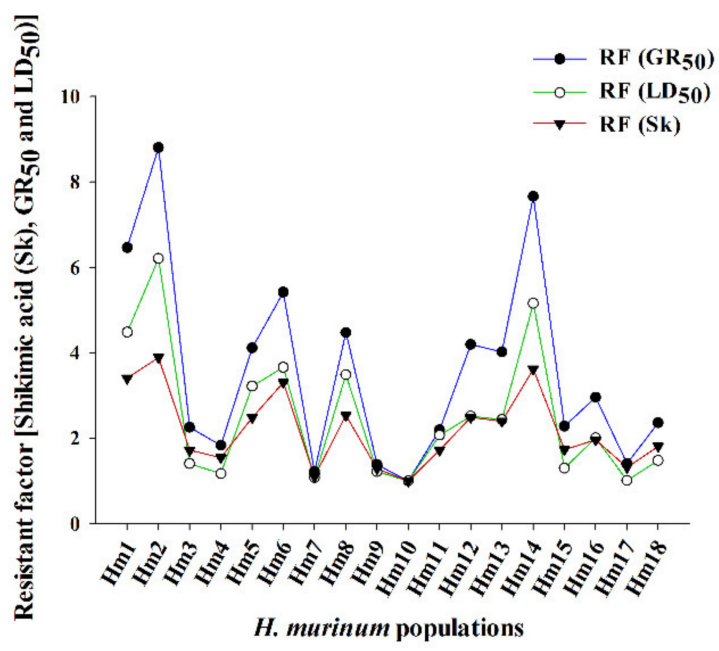

Figure 3. Relation between resistant factor (RF) of Shikimic acid, $\mathrm{GR}_{50}$ and $\mathrm{LD}_{50}$ for $18 \mathrm{H}$. murinum populations from Spain. Population Hm10 was the reference $S$ population to estimate RF.

$\mathrm{LD}_{50}$ values for the eighteen $H$. murinum populations were plotted together with the field recommend rates for glyphosate in Spain, United Kingdom and Australia (Figure 4). The Spanish field dose doubles the Australian and English ones. Therefore, referring to a R population by the $\mathrm{LD}_{50}$ value is quite subjective from an agronomic perspective, as the dose used in the field varies between countries [25-27]. For example, in this study eight populations were classified as R according to the RF $\left(\mathrm{GR}_{50}\right)$ [14]. Nevertheless, although six had $\mathrm{LD}_{50}$ values equal or above the Spanish field recommended dose, 10 were already above the recommended dose in Australia (Figure 4).

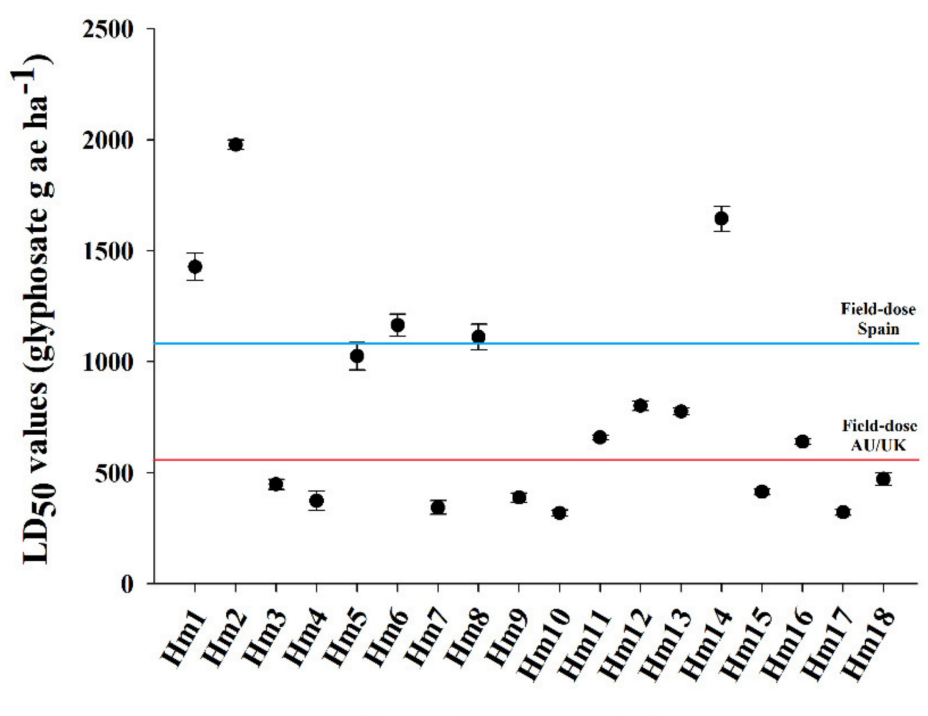

H. murinum populations

Figure 4. $\mathrm{LD}_{50}$ values for eighteen $H$. murinum populations from Spain. Blue and red lines represent the field recommend doses in Spain (1080 $\mathrm{g}$ ae ha $\left.{ }^{-1}\right)$ and Australia plus UK (540 $\mathrm{g}$ ae ha $\left.{ }^{-1}\right)$, respectively. 
The two tested adjuvants-Retenol and Trend 90-clearly increased glyphosate efficacy in both S and $\mathrm{R}$ H. murinum populations (Table 4). These results were in accordance with increased herbicide foliar retention observed in this study on both populations with the addition of both adjuvants (Table 5). Adjuvants, either included in formulated products or added in the tank mixtures, have been found to improve glyphosate performance in different ways, such as improving spray retention on the leaf surface [43]. Therefore, adding the most suitable adjuvants could not only maintain glyphosate efficacy against $\mathrm{S}$ and $\mathrm{R} H$. murinum, but also reduce environmental impacts thanks to lower doses of herbicides [40]. This tool should also be considered to design better chemical programs, because maximizing efficacy at field recommended rates is crucial to prevent the evolution and spreading of herbicide resistance [20,21]. Finally, Trend 90, a non-ionic surfactant, was better in increasing glyphosate efficacy thanks to a better foliar retention than Retenol, a terpene alcohol obtained from pine resin (according to manufacturers). Non-ionic surfactants are better in increasing foliar retention than plant derived adjuvants most suitable to reduce drift [44].

This study demonstrated that it is possible to control glyphosate $\mathrm{R} H$. murinum populations applying herbicides with alternative SoA, such as PS II, PS I, and ACCase inhibitors. These results are in agreement with previous studies where these SoA were effective in controlling other Hordeum species (reviewed in [4]). On the other hand, insufficient control levels with ALS inhibitors in POST have been previously reported too [4], because herbicides such as iodosulfuron usually need an admixture partner. In this research, different herbicides both in PRE and POST were good alternatives in controlling H. murinum, which should aid in designing improved chemical programs to manage these glyphosate $\mathrm{R}$ populations. To prevent the evolution of herbicide resistance, recent studies point out that it is better to (tank) mix alternative herbicides with different SoA rather than rotating them in sequential applications [45]. Unfortunately, H. murinum is able to evolve herbicide resistance to all the above-mentioned SoA [14,46]. Therefore, growers must use IWM strategies, involving combinations of all weed control tactics available, such as mechanical, biological, and cultural together with chemical to effectively manage them [47].

\section{Conclusions}

The overuse of glyphosate can promote the evolution of resistance in H. murinum subsp. leporinum. This study confirmed the first case of glyphosate resistance in this subspecies in the world. It also represents the first resistance case to any herbicide in Europe. Chemical control with herbicides with different SoA should be the choice for an improved IWM program. The best chemical options for both glyphosate $S$ and R populations were ACCase (propaquizafop and quizalafop), PS I (paraquat), and PS II (atrazine) inhibiting herbicides. Moreover, adjuvants should be considered when designing chemical programs to prevent resistance because they enhance glyphosate efficacy through increased herbicide foliar retention. The presence of glyphosate $\mathrm{R} H$. murinum populations in southern Spain, particularly in olive orchards, highlights the necessity to advocate for a more sustainable use of this herbicide and implement IWM strategies including non-chemical tools.

Author Contributions: Conceptualization, J.G.V.-G., P.C., J.T., and R.D.P.; methodology, J.G.V.-G., P.C., J.T., R.A.-d.l.C., and R.D.P.; software, J.G.V.-G., P.C., J.T., R.A.-d.l.C., and R.D.P.; validation, J.G.V.-G., P.C., J.T., and R.D.P.; formal analysis, J.G.V.-G., P.C., and R.A.-d.1.C.; investigation, J.G.V.-G., P.C., J.T., R.A.-d.l.C., and R.D.P.; resources, J.T. and R.D.P.; data curation, J.G.V.-G. and P.C.; writing-original draft preparation, J.G.V.-G., P.C., J.T., and R.D.P.; writing-review and editing, J.G.V.-G., P.C., J.T., R.A.-d.1.C., and R.D.P.; visualization, J.G.V.-G., P.C., J.T., R.A.-d.l.C., and R.D.P.; supervision, R.D.P.; project administration, J.T. and R.D.P.; funding acquisition, J.T. and R.D.P. All authors have read and agreed to the published version of the manuscript.

Funding: This research has also been supported by the Spanish Government, through project AGL2017-83325 -C4-2-R (AEI/FEDER/UE), Asociación de Agroquímicos y Medioambiente and project ref PO 4513358935 by Bayer CropScience.

Acknowledgments: Joel Torra acknowledges support from the Spanish Ministry of Science, Innovation and Universities (grant Ramon y Cajal RYC2018-023866-I). The authors are grateful to Rafael Zamorano García for their technical help. 
Conflicts of Interest: The authors declare no conflicts of interest. The funders had no role in the design of the study; in the collection, analyses, or interpretation of data; in the writing of the manuscript; or in the decision to publish the results.

\section{References}

1. Ruíz-Ferna, J.; Soler, C. Distribution and habitat of Spanish populations of the subtribe Hordeineae; improved views following germplasm collecting activities. Genet. Resour. Crop. Evol. 1997, 44, 33-41. [CrossRef]

2. León, E.; Nieto, E.L.; Martínez, M.L.; Salvá, A.J.P. El agregado de Hordeum murinum (Poaceae) en “Flora Iberica". Acta Bot. Malacit. 2019, 39, 311-319. [CrossRef]

3. Barkworth, M.E.; Von Bothmer, R.; Jacobsen, N.; Baden, C.; Jorgensen, R.B.; Linde-Laursen, I. An Ecogeographical Study of the Genus Hordeum. In Systematic and Ecogeographic Studies on Crop Genepools, 2nd ed.; International Plant Genetic Resources Institute: Rome, Italy, 1995; p. 129.

4. Iqbal, N.; Bajwa, A.A.; Manalil, S.; Khan, A.M.; Kebaso, L.; Frimpong, D.; Ali, H.H.; Jha, P.; Chauhan, B.S. Biology and management of two Hordeum weedy species: A review. Crop. Prot. 2019, 125, 104908. [CrossRef]

5. Powles, S. Appearance of a biotype of the weed, Hordeum glaucum Steud., resistant to the herbicide paraquat. Weed Res. 1986, 26, 167-172. [CrossRef]

6. Tucker, E.S.; Powles, S. A Biotype of Hare Barley (Hordeum leporinum) Resistant to Paraquat and Diquat. Weed Sci. 1991, 39, 159-162. [CrossRef]

7. Davis, R.C. Agrichemical Industry Initiatives to Combat Development of Herbicide Resistance. In Proceedings of the 1st Internat Weed Control Cong, Melbourne, Australia, 17-21 February 1992; Volume 2, pp. $144-147$.

8. Purba, E.; Preston, C.; Powles, S. The mechanism of resistance to paraquat is strongly temperature dependent in resistant Hordeum leporinum Link and H. glaucum Steud. Planta 1995, 196, 464-468. [CrossRef]

9. Alizadeh, H.; Preston, C.; Powles, S. Paraquat-resistant biotypes of Hordeum glaucum from zero-tillage wheat. Weed Res. 1998, 38, 139-142. [CrossRef]

10. Matthews, N.; Powles, S.B.; Preston, C. Mechanisms of resistance to acetyl-coenzyme A carboxylase-inhibiting herbicides in a Hordeum leporinum population. Pest Manag. Sci. 2000, 56, 441-447. [CrossRef]

11. Yu, Q.; Nelson, J.K.; Zheng, M.Q.; Jackson, M.; Powles, S.B. Molecular characterization of resistance to ALS-inhibiting herbicides in Hordeum leporinum biotypes. Pest Manag. Sci. 2007, 63, 918-927. [CrossRef]

12. Owen, M.J.; Goggin, D.E.; Powles, S.B. Identification of resistance to either paraquat or ALS-inhibiting herbicides in two Western Australian Hordeum leporinum biotypes. Pest Manag. Sci. 2012, 68, 757-763. [CrossRef]

13. Adu-Yeboah, P.; Malone, J.M.; Fleet, B.; Gill, G.; Preston, C. EPSPS gene amplification confers resistance to glyphosate resistant populations of Hordeum glaucum Stued (northern barley grass) in South Australia. Pest Manag. Sci. 2019, 76, 1214-1221. [CrossRef]

14. Heap, I. International Survey of Herbicide Resistant Weeds. Available online: http://weedscience.org/ (accessed on 26 March 2020).

15. Duke, S.O.; Powles, S.B. Glyphosate: A once-in-a-century herbicide. Pest Manag. Sci. 2008, 64, 319-325. [CrossRef] [PubMed]

16. Duke, S.O. Glyphosate: The world's most successful herbicide under intense scientific scrutiny. Pest Manag. Sci. 2018, 74, 1025-1026. [CrossRef] [PubMed]

17. Boocock, M.R.; Coggins, J.R. Kinetics of 5-enolpyruvylshikimate-3-phosphate synthase inhibition by glyphosate. FEBS Lett. 1983, 154, 127-133. [CrossRef]

18. Velini, E.D. Modo de Acao Do Glyphosate. In Glyphosate; Velini, E.D., Meschede, D.K., Carbonari, C.A., Trindade, M.L.B., Eds.; Fepaf: Botucato, Brazil, 2009; pp. 113-133.

19. Sammons, R.D.; Gaines, T.A. Glyphosate resistance: State of knowledge. Pest Manag. Sci. 2014, 70, 1367-1377. [CrossRef]

20. Moss, S. Herbicide Resistance in Weeds. In Weed Research: Expanding Horizons; Hatcher, P.E., Froud-Williams, R.J., Eds.; Wiley: Hoboken, NJ, USA, 2017; pp. 181-214.

21. Beffa, R.; Menne, H.; Köcher, H. Herbicide Resistance Action Committee (HRAC). Available online: https://www.hracglobal.com (accessed on 6 April 2020).

22. Powles, S.; Yu, Q. Evolution in Action: Plants Resistant to Herbicides. Annu. Rev. Plant Boil. 2010, 61, 317-347. [CrossRef] 
23. Michitte, P.; De Prado, R.; Espinosa, N.; Gauvrit, C. Glyphosate resistance in a Chilean Lolium multiflorum. Commun. Agric. Appl. Boil. Sci. 2005, 70, 507-513.

24. Fernández-Moreno, P.T.; La Cruz, R.A.-D.; Smeda, R.J.; De Prado, R. Differential Resistance Mechanisms to Glyphosate Result in Fitness Cost for Lolium perenne and L. multiflorum. Front. Plant Sci. 2017, 8, 8. [CrossRef]

25. Brunharo, C.; Patterson, E.; Carrijo, D.; De Melo, M.S.C.; Nicolai, M.; A Gaines, T.; Nissen, S.J.; Christoffoleti, P. Confirmation and mechanism of glyphosate resistance in tall windmill grass (Chloris elata) from Brazil. Pest Manag. Sci. 2016, 72, 1758-1764. [CrossRef]

26. Ngo, T.D.; Krishnan, M.; Boutsalis, P.; Gill, G.; Preston, C. Target-site mutations conferring resistance to glyphosate in feathertop Rhodes grass (Chloris virgata) populations in Australia. Pest Manag. Sci. 2017, 74, 1094-1100. [CrossRef]

27. Bracamonte, E.; Da Silveira, H.M.; La Cruz, R.A.-D.; Domínguez-Valenzuela, J.A.; Cruz-Hipolito, H.E.; De Prado, R. From tolerance to resistance: Mechanisms governing the differential response to glyphosate in Chloris barbata. Pest Manag. Sci. 2018, 74, 1118-1124. [CrossRef] [PubMed]

28. Vazquez-Garcia, J.G.; Golmohammadzadeh, S.; Palma-Bautista, C.; Rojano-Delgado, A.M.; DomínguezValenzuela, J.A.; Cruz-Hipólito, H.E.; De Prado, R. New Case of False-Star-Grass (Chloris distichophylla) Population Evolving Glyphosate Resistance. Agronomy 2020, 10, 377. [CrossRef]

29. Gaines, T.A.; Cripps, A.; Powles, S.B. Evolved Resistance to Glyphosate in Junglerice (Echinochloa colona) from the Tropical Ord River Region in Australia. Weed Technol. 2012, 26, 480-484. [CrossRef]

30. Alarcón-Reverte, R.; Garcia, A.; Urzúa, J.; Fischer, A.J. Resistance to Glyphosate in Junglerice (Echinochloa colona) from California. Weed Sci. 2013, 61, 48-54. [CrossRef]

31. Nandula, V.K.; Montgomery, G.B.; Vennapusa, A.R.; Jugulam, M.; Giacomini, D.A.; Ray, J.D.; Bond, J.A.; Steckel, L.E.; Tranel, P. Glyphosate-Resistant Junglerice (Echinochloa colona) from Mississippi and Tennessee: Magnitude and Resistance Mechanisms. Weed Sci. 2018, 66, 603-610. [CrossRef]

32. De Carvalho, L.B.; Alves, P.L.C.A.; González-Torralva, F.; Cruz-Hipolito, H.E.; Rojano-Delgado, A.M.; De Prado, R.; Gil-Humanes, J.; Barro, F.; De Castro, M.D.L. Pool of Resistance Mechanisms to Glyphosate in Digitaria insularis. J. Agric. Food Chem. 2012, 60, 615-622. [CrossRef] [PubMed]

33. Vila-Aiub, M.M.; Balbi, M.C.; Gundel, P.E.; Ghersa, C.M.; Powles, S.B. Evolution of Glyphosate-Resistant Johnsongrass (Sorghum halepense) in Glyphosate-Resistant Soybean. Weed Sci. 2007, 55, 566-571. [CrossRef]

34. Riar, D.S.; Norsworthy, J.K.; Johnson, D.B.; Scott, R.C.; Bagavathiannan, M. Glyphosate Resistance in a Johnsongrass (Sorghum halepense) Biotype from Arkansas. Weed Sci. 2011, 59, 299-304. [CrossRef]

35. Vazquez-Garcia, J.G.; Palma-Bautista, C.; Rojano-Delgado, A.M.; De Prado, R.; Menendez, J. The First Case of Glyphosate Resistance in Johnsongrass (Sorghum halepense (L.) Pers.) in Europe. Plants 2020, 9, 313. [CrossRef]

36. Infante-Amate, J.; Villa, I.; Aguilera, E.; Torremocha, E.; Guzmán, G.; Cid, A.; Emanueli, F. The Making of Olive Landscapes in the South of Spain. A History of Continuous Expansion and Intensification. In Biocultural Diversity in Europe; Agnoletti, M., Emanueli, F., Eds.; Springer: New York, NY, USA, 2017; pp. 157-159.

37. Márquez-García, F.; González-Sánchez, E.J.; Castro-Garcia, S.; Ordóñez-Fernández, R. Improvement of soil carbon sink by cover crops in olive orchards under semiarid conditions. Influence of the type of soil and weed. Span. J. Agric. Res. 2013, 11, 335. [CrossRef]

38. Galán, C.; García-Mozo, H.; Vázquez, L.; Ruiz, L.; de la Guardia, C.D.; Domínguez-Vilches, E. Modeling Olive Crop Yield in Andalusia, Spain. Agron. J. 2008, 100, 98-104. [CrossRef]

39. Shaner, D.L.; Nadler-Hassar, T.; Henry, W.B.; Koger, C.H. A rapid in vivo shikimate accumulation assay with excised leaf discs. Weed Sci. 2005, 53, 769-774. [CrossRef]

40. Palma-Bautista, C.; Vazquez-Garcia, J.G.; Travlos, I.; Tataridas, A.; Kanatas, P.; Domínguez-Valenzuela, J.A.; De Prado, R. Effect of Adjuvant on Glyphosate Effectiveness, Retention, Absorption and Translocation in Lolium rigidum and Conyza canadensis. Plants 2020, 9, 297. [CrossRef] [PubMed]

41. Gauvrit, C. Glyphosate Response to Calcium, Ethoxylated Amine Surfactant, and Ammonium Sulfate. Weed Technol. 2003, 17, 799-804. [CrossRef]

42. Ritz, C.; Baty, F.; Streibig, J.C.; Gerhard, D. Dose-Response Analysis Using R. PLoS ONE 2015, 10 , e0146021. [CrossRef]

43. Travlos, I.; Cheimona, N.; Bilalis, D. Glyphosate Efficacy of Different Salt Formulations and Adjuvant Additives on Various Weeds. Agronomy 2017, 7, 60. [CrossRef]

44. De Oliveira, R.B.; Antuniassi, U.R.; Mota, A.A.B.; Chechetto, R.G. Potential of adjuvants to reduce drift in agricultural spraying. Eng. Agrícola 2013, 33, 986-992. [CrossRef] 
45. Evans, J.A.; Tranel, P.J.; Hager, A.G.; Schutte, B.; Wu, C.; Chatham, L.A.; Davis, A.S. Managing the evolution of herbicide resistance. Pest Manag. Sci. 2015, 72, 74-80. [CrossRef]

46. Shergill, L.; Fleet, B.; Preston, C.; Gill, G.; Gill, G. Incidence of Herbicide Resistance, Seedling Emergence, and Seed Persistence of Smooth Barley (Hordeum glaucum) in South Australia. Weed Technol. 2015, 29, 782-792. [CrossRef]

47. Beckie, H.J.; Tardif, F.J. Herbicide cross resistance in weeds. Crop. Prot. 2012, 35, 15-28. [CrossRef] 